\title{
Systematic review of Kabuki Syndrome's phenotype with KMT2D gene
} mutation

Leonardo Bonini Fischetti ${ }^{i}$

Julia Zaccarelli Magalhães ${ }^{\text {ii }}$

André Rinaldi Fukushima ${ }^{\text {iii }}$

Paula Waziry ${ }^{\text {iv }}$

Esther Lopes Ricciv

\section{Registro DOI: http://dx.doi.org/10.22280/revintervol12ed1.426}

\begin{abstract}
Kabuki Syndrome is rare and poorly documented, initially mentioned by Niikawa and Kuroki in 1981. The prevalence of the syndrome among live births is 1:32,000. Case reports are now available, which correlates to improved techniques for accurate diagnosis. This study focused on a systematic comparative review of the phenotypes of individuals with Kabuki Syndrome, with the purpose to facilitate diagnosis. The systematic review was done with a bibliographic survey of case studies using the following databases: Pubmed, Science Direct and Google Scholar, in conjunction with the following key-words: Kabuki syndrome, phenotype, KMT2D and case report. The literature shows that patients with this syndrome present five main characteristics, besides several types of secondary phenotypes. These characteristics present variations in permeability as well as expressivity of some genes in individuals, therefore, a characterization through phenotype alone becomes limited, making it necessary to perform genetic analysis for differential diagnosis. In order to increase the knowledge and elucidate mechanisms of Kabuki syndrome, we suggest further studies that utilize animal models.
\end{abstract}

Key words: Kabuki syndrome. Phenotype. KMT2D. Case report.

\section{Revisão sistemática do fenótipo da síndrome de kabuki com mutação no gene kmt2d}

\section{Resumo}

A Síndrome de Kabuki é rara e pouco relatada, sendo descrita somente por Niikawa e Kuroki em 1981. Apresenta esse nome devido à similaridade com a maquiagem dos atores do teatro de Kabuki. Sua relação é de 1:32.000 entre os nascidos vivos. Contudo, os relatos de casos estão aumentando podendo estar relacionado com o aumento das técnicas para diagnóstico final. Este trabalho tem como objetivo realizar uma revisão sistemática comparando o fenótipo dos indivíduos com Síndrome de Kabuki, a fim de facilitar seu diagnóstico. A revisão sistemática foi feita com um levantamento bibliográfico de relatos de caso obtidos através das bases de dados: Pubmed, Science Direct e Google Acadêmico; com as seguintes palavras-chaves: kabuki syndrome, phenotype, KMT2D e case report.. Os resultados mostraram que os portadores desta síndrome apresentam as cinco características principais, além de diversos tipos de alterações secundárias atreladas com a síndrome. Essas características apresentam variações em intensidade e presença nos indivíduos, portanto, a caracterização através do fenótipo se torna 
limitada, sendo necessário um exame genético para o diagnóstico diferencial. Para ampliar o conhecimento sobre Kabuki, sugerimos a realização de estudos em modelos animais a fim de entender os mecanismos gerais relacionados com essa síndrome.

Palavras-chave: Síndrome de Kabuki, fenótipo, KMT2D e relato de caso.

\section{Recebido em 15/01/2019 Aceito em 30/01/2019}

\section{INTRODUCTION}

Point mutations are a type of genetic mutation that occur through the addition, deletion or substitution of nitrogenous bases at a locus of a chromosome, capable of causing a genetic disease (JORDE et al., 2004). In general, these diseases are congenital and can be classified as either monogenic when it occurs due to mutation of a single gene or multifactorial, when caused by other factors such as the environment and involvement of multiple genes (JUNIOR; IANOTTI, 2010).

Kabuki syndrome is a rare multifactorial congenital genetic disease with a ratio of 1: 32,000 live births (LU et al., 2016). It is also called Kabuki Makeup Syndrome or Niikawa-Kuroki Syndrome due to the presence of abnormal facial characteristics, which resemble the makeup of actors from the Japanese traditional Kabuki theater (KUROKI et al., 1981; NIIKAWA et al., 1981). According to Niikawa and Matsumoto (2003), there are five main phenotypic characteristics found in all affected patients: 1) facial anomalies; 2) presence of mental retardation (mild to moderate); 3) delayed postnatal growth and/or development; 4) anomalies in skeletal structure; and 5) uncommon dermatoglyphic patterns.

In addition to the main phenotypes used for the diagnosis of Kabuki Syndrome, there are other possible complications involved. According to Adam and Hudgins (2005), cardiac, renal, genital, immune and hearing loss problems, among others, were also found in Kabuki patients. Although there is no defined genetic pattern for Kabuki Syndrome mutations, laboratory analyzes have shown that the main genes involved for its development are KMT2D and KDM6A, accounting for $44 \%$ to $76 \%$ and $9 \%$ to $13 \%$ of cases, respectively (VAN LAARHOVEN et al., 2015; MIYAKE et al., 2013).

The KMT2D gene, also called MLL2, is located on chromosome 12 and has 54 exons. Patients with Kabuki Syndrome have mutations that result in loss of function of the gene encoding the 2D lysine methyltransferase protein (LU et al., 2016). Current methods used to detect Kabuki 


\section{Revinter}

mutations are Sanger sequencing and comparative genomic hybridization (aCGH) (NG et al., 2010).

Kabuki's syndrome is rare and sparingly reported in the scientific milieu, since its description by Niikawa and Kuroki in 1981. Its incidence, however, has increased, especially when taking into consideration specific case reports. This increase in incidence may reflect improved sensitivity of analytical techniques used in diagnosis, or even increased epigenetic or other unknown factors. An important fact to be taken into account in this complex context is that descriptions in the scientific literature do not represent a consensus regarding the phenotypical characteristics of this Syndrome, which makes its diagnosis quite challenging. Thus, the objective of this work was to perform a systematic review of case reports in order to compare the phenotypes of individuals with Kabuki Syndrome.

\section{METHODS}

To carry out the systematic review, a bibliographic survey of case reports was obtained through Pubmed, Science Direct and Google Academic databases. The following keywords were used to perform the research: Kabuki syndrome, phenotype, KMT2D and case report. The following filters were used as inclusion criterion:

$$
\begin{aligned}
& \text { - } \quad \text { Languages: English; } \\
& \text { - } \quad \text { Species: humans; } \\
& \text { - } \quad \text { Types of articles: clinical case reports; } \\
& \text { Period of publication of articles: } 1981 \text { to } 2018 .
\end{aligned}
$$

Publication search was performed by an advanced method in which three key words were correlated, being at least one key word related to phenotypic aspects. From all the correlations of used key words, we had retrieved 471 articles. The following exclusion criteria were used:

- Duplicate articles;

- Absence of citation of phenotypic characteristics;

- Articles in other languages;

- Articles that did not contain case reports.

Remaining articles were examined by reading the abstract and further excluding publications that had no correlation with the key mentioned above. A total of 7 case reports met the criteria for inclusion. These articles only cited Kabuki Syndrome when compared to other genetic syndromes. The analysis of results was performed by tabulating the articles according to the patients' phenotypes. 


\section{Revinter}

\section{RESULTS}

Review of the 7 selected publications included the evaluation of a total of 26 individuals with Kabuki Syndrome. Table 1 presents the five main phenotypic characteristics of these patients, as well as the associated genotypes. The presence (+) or absence (-) of each evaluated parameter is shown for each individual, with the exception of those not mentioned (NM) in the literature. Facial characteristics (FC) were considered when the patient presented one or more of the following: arched eyebrows, wide palpebral fissure, long nose with depression at the tip, broad ears with unusual shape, long eyelashes, palate and ectropion. Structural alterations (SA), as well as facial features, were in concordance with the manifestation of one or more of the following factors: scoliosis, joint problems, skeletal malformation, micrognathia and clinodactyly. The parameters used to characterize the presence or absence of issues with dermatoglyphic patterns (DP) included the presence of finger pads and/or any issue related to the palms and soles of the feet.

In order to correctly diagnose mental retardation (MR), the patients underwent specific tests and in some cases assessment of IQ was performed. The IQ values followed the classification of Terman, presenting variations between certain classifications: reasoning far below average (20-49), slow reasoning (50-69), borderline (70-79), dullness (80-89), normal intelligence (90109), intelligence above average (110-120) and gifted intelligence (121-130). In order to determine the presence of delayed postnatal development (DPD), patients were subjected to evaluations that determined possible delays in characteristic milestones such as: speech, standing between the first and second year of life, and difficulty in understanding words.

To perform genetic tests, DNA was sequenced using techniques such as Sanger and comparative genomic hybridization (aCGH), which indicated the type of mutation, the modified codon for respective protein translation and the exon where such mutation was found. 
Table 1 - Description of the main phenotypic and genotypic characteristics of Kabuki Syndrome.

\begin{tabular}{|c|c|c|c|c|c|c|c|c|c|}
\hline Patient & Study & FC & SA & DP & MR* & DPD & Mutation & Modified Protein & Exon / Intron \\
\hline 1 & Lindsley et al. (2016) & + & NM & NM & NM & + & c. $3754 \mathrm{C}>\mathrm{T}$ & p.R1252X & 11 \\
\hline 2 & Lindsley et al. (2016) & + & + & NM & NM & - & c.303del & p.S102AfsX28 & 3 \\
\hline 3 & Lindsley et al. (2016) & + & + & NM & NM & + & c. $5783-1 \mathrm{G}>\mathrm{A}$ & & 26(intron) \\
\hline 4 & Lindsley et al. (2016) & + & + & NM & NM & + & c. $7426 \mathrm{G}>\mathrm{T}$ & p.E2476X & 31 \\
\hline 5 & Lindsley et al. (2016) & + & + & NM & + & - & c. $15461 G>A$ & p.R5154Q & 48 \\
\hline 6 & Lindsley et al. (2016) & + & NM & NM & + & + & c. $15104 \mathrm{G}>\mathrm{C}$ & p.C5035S & 48 \\
\hline 7 & Lindsley et al. (2016) & + & + & NM & + & + & c. $6183+\mathrm{G}>\mathrm{T}$ & & 29(intron) \\
\hline 8 & Lindsley et al. (2016) & + & + & NM & + & + & c. $16294 \mathrm{C}>\mathrm{T}$ & p.R5432W & 51 \\
\hline 9 & Lindsley et al. (2016) & + & NM & NM & + & + & c.2008insT & p.P669SfX6 & 10 \\
\hline 10 & Lindsley et al. (2016) & + & + & NM & + & - & c.6844delC & p.R2282GfsX3 & 31 \\
\hline 11 & Genevieve et al. (2004) & + & NM & + & $+(50)$ & + & NM & NM & NM \\
\hline 12 & Genevieve et al. (2004) & + & + & + & $+(62)$ & + & NM & NM & NM \\
\hline 13 & Genevieve et al. (2004) & + & NM & + & NM & NM & NM & NM & NM \\
\hline 14 & Genevieve et al. (2004) & + & + & + & + & NM & NM & NM & NM \\
\hline 15 & Genevieve et al. (2004) & + & + & + & + & + & NM & NM & NM \\
\hline 16 & Genevieve et al. (2004) & + & + & + & NM & + & NM & NM & NM \\
\hline 17 & Genevieve et al. (2004) & + & + & + & + & + & NM & NM & NM \\
\hline 18 & Genevieve et al. (2004) & + & + & + & + & + & NM & NM & NM \\
\hline 19 & Long et al. (2016) & NM & NM & + & NM & - & c. $1383 \mathrm{Y}$ & p. $4148 \mathrm{G}>\mathrm{A}$ & 14 \\
\hline 20 & Long et al. (2016) & + & NM & + & NM & + & c. $3121 \mathrm{C}>\mathrm{T}$ & p.Q1041X & 14 \\
\hline 21 & Bögershausen et al., 2016 & + & NM & + & + & NM & c. $10588 \mathrm{delC}$ & p.Glu3530Serfs*128 & 38 \\
\hline 22 & Schulz et al., 2014 & + & + & NM & + & NM & c. $5263 \mathrm{C}>\mathrm{T}$ & p.Gln1755 & 22 \\
\hline 23 & Badalato et al., 2016 & + & + & + & NM & NM & c. $10725 \mathrm{G}>\mathrm{C}$ & p.Gln 3575 His & NM \\
\hline 24 & Badalato et al., 2016 & + & NM & + & + & + & c. $10725 \mathrm{G}>\mathrm{C}$ & p.Gln $3575 \mathrm{His}$ & NM \\
\hline 25 & Badalato et al., 2016 & + & + & + & + & + & c. $10725 \mathrm{G}>\mathrm{C}$ & p.Gln $3575 \mathrm{His}$ & NM \\
\hline 26 & Karagianni et al., 2016 & + & $\mathrm{NM}$ & + & + & + & c.7370_7378insT & p.Ser2438Ilefs $* 11$ & 31 \\
\hline
\end{tabular}

FC: Facial characteristics; SA: Structural alterations; DP: dermatoglyphic patterns; MR mental retardation; DPD: delayed postnatal development; NM: not mentioned; +: presence; - absence, *non-phenotypic characteristic. 
In addition to the main phenotypic characteristics described for each of the patients, other malformations and alterations were found. Table 2 and Table 3 present the description of each of the secondary characteristics found for each patient. Since each individual presented a clinical picture that was different from the others, a graph was derived in order to quantify the frequency of secondary characteristics based on their presence or absence (Fig. 1).

Table 2 - Description of secondary characteristics of Kabuki Syndrome.

\begin{tabular}{|c|c|c|}
\hline Characteristics & Initials & Description \\
\hline Cardiac Malformations * & $\mathrm{CM}$ & $\begin{array}{l}\text { - Ventricular septal defect } \\
\text { - Atrial septal defect } \\
\text { - Atrial atresia } \\
\text { - Mitral atresia } \\
\text { - Aortic coarctation }\end{array}$ \\
\hline Genital Malformations & GM & - Cryptorchidism \\
\hline Ophthalmologic Alteration & $\mathrm{OA}$ & $\begin{array}{l}\text { - Coloboma } \\
\text { - Microphthalmia } \\
\text { - Ptose }\end{array}$ \\
\hline Deafness * & $\mathrm{DE}$ & $\begin{array}{l}\text { - Sensorineural hearing loss } \\
\text { - Conductive hearing loss }\end{array}$ \\
\hline Hyperlaxia & HL & - Increased joint flexibility \\
\hline Infections * & IFN & $\begin{array}{l}\text { - Recurrent viral or bacterial infections } \\
\text { - Pneumonia } \\
\text { - Urinary tract infections } \\
\text { - Otitis media }\end{array}$ \\
\hline Immune System Alterations* & ISA & $\begin{array}{l}\text { - Autoimmune diseases } \\
\text { - Lymphocytes alterations } \\
\text { - Immunoglobulin alterations } \\
\text { - Alteration in neutropenia } \\
\text { - Alteration in thrombopenia } \\
\text { - Eczema }\end{array}$ \\
\hline Renal Alterations * & RA & $\begin{array}{l}\text { - Renal hypoplasia } \\
\text { - Double collector system } \\
\text { - Duplicate right kidney }\end{array}$ \\
\hline Microcephaly & MC & - Head size much smaller compared to other babies \\
\hline Gastrointestinal Disorders * & GD & $\begin{array}{l}\text { - Digestive alteration } \\
\text { - Diarrhea } \\
\text { - Celiac disease } \\
\text { - Poor absorption of nutrients } \\
\text { - Lactose intolerance }\end{array}$ \\
\hline Hypotonia & HPT & - Low muscle tone and reduced muscle strength \\
\hline Micrognathism & MCG & - Condition where the jaw is undersized \\
\hline Malformation in Diaphragm * & MD & - Alteration in diaphragm muscle shape \\
\hline Hypoglycemia * & HPG & - Blood sugar decreases to below normal levels \\
\hline Dysplasia & DYS & - Abnormal development of cells within tissues or organs \\
\hline Polydramnia * & PL & - Amniotic fluid change in maternal uterus \\
\hline Accumulation of Bilirubin * & $\mathrm{AB}$ & - Excess blood bilirubin \\
\hline Seizures * & SE & - Sudden abnormal electrical activity in the brain \\
\hline
\end{tabular}

* non-phenotypic characteristic. 


\section{Revinter}

Figure 1 - Secondary characteristics found in patients with Kabuki Syndrome.

\section{Secondary Characteristics}

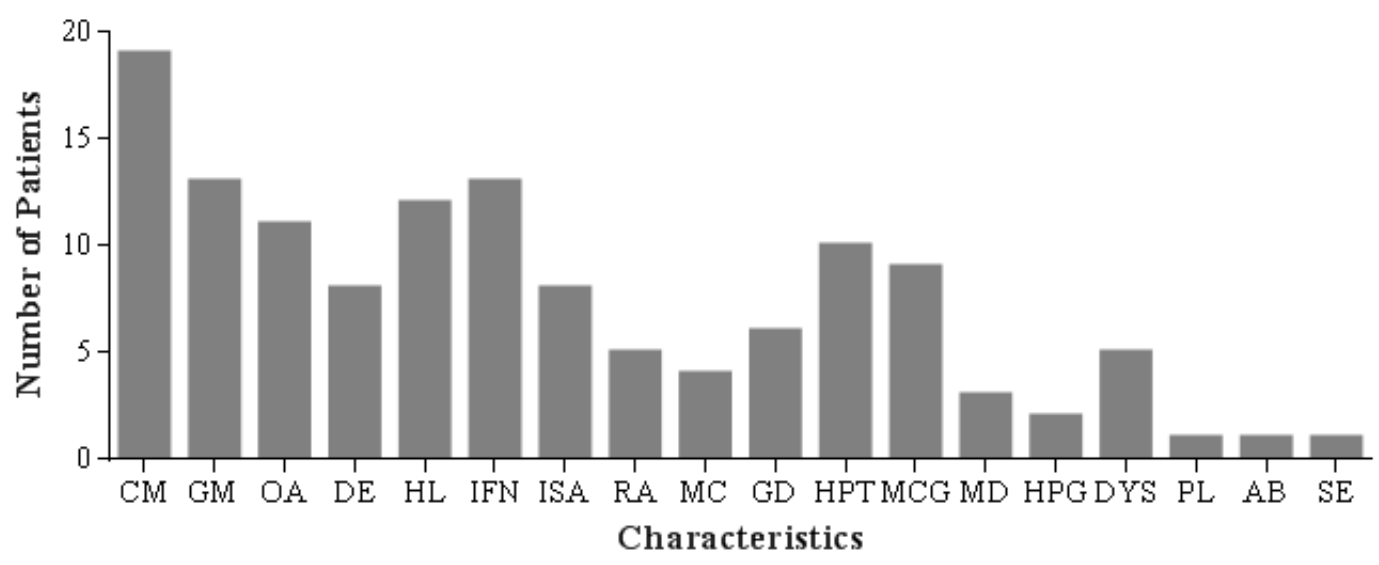

CM: cardiac malformations; GM: genital malformations; OA: ophthalmologic alteration; DE: deafness; HL: hyperlaxia; IFN: infections; ISA: immune system alterations; RA: renal alterations; MC: microcephaly; GD: gastrointestinal disorders; HPT: hypotonia; MCG: micrognathism; MD: malformation in diaphragm; HPG: hypoglycemia; DYS: dysplasia; PL: polydramnia; AB: accumulation of bilirubin; SE: seizures.

\section{DISCUSSION}

A systematic review is a scientific investigation that aims to integrate relevant studies using literature databases, thus increasing the knowledge about a certain subject (SAMPAIO; MANCINI, 2007). Kabuki Syndrome has recently been described and it's considered as rare, therefore, the objective of this work was to carry out a systematic review of case reports referring to characteristic phenotypes of individuals with this syndrome, in order to increase knowledge about the disease and facilitate diagnosis.

Kabuki syndrome is a multifactorial genetic disease caused by congenital chromosomal mutations (CARVALHO et al., 2006). Although the genetic pattern of this syndrome has not yet been confirmed, studies point to KMT2D and KDM6A genes as the main genes involved for development of phenotypes (VAN LAARHOVEN et al., 2015; MIYAKE et al., 2013). Since the KMT2D gene is known to be responsible for approximately $70 \%$ of Kabuki cases, it was elected as the focus of the present work.

This review was based on 7 case reports, in which phenotypic characteristics of 26 patients were described and compared. Overall, comparative results showed that Kabuki syndrome is still poorly described in the literature and surrounded by controversies when solely phenotypic characteristics are taken into consideration for evaluation of affected individuals. Thus, despite the main intention of this work to concentrate on phenotypic characterization of this syndrome, we have also elected to give a general overview of all described characteristics in the case reports analyzed, which included physiological, morphological and immunological aspects. 


\section{Revinter}

All patients, with the exception of patient 19 whose facial features were not mentioned, presented typical Kabuki Syndrome physiognomy. Mhanni et al. (1999) showed that all individuals with this syndrome presented similar physiognomy, which simplified the recognition of the syndrome in childhood. Three other case reports from different authors have shown $100 \%$ of physiognomy changes that are typical of the syndrome (MCGAUGHRAN et al., 2001; LEPRI et al., 2017; XIN et al., 2018), suggesting that such observations are of considerable importance and make it possible to diagnose the syndrome based on phenotype. Skeletal changes are not specific and may be expressed in the hands and/or vertebrae (PHILIP et al., 1992), such as clinodactyly, displacement of some joints, scoliosis and other vertebral abnormalities (ADAM; HUDGINS, 2005). All patients examined who presented alterations in the skeleton, regardless of Kabuki diagnosis, exhibited one or more of the diagnostic criteria mentioned above, indicating that such skeletal malformations are common and not specific for Kabuki Syndrome.

The described dermatoglyphic patterns refer to the dermal crests on the toes, palms and soles of the feet (NASSAU et al., 2006). In Kabuki Syndrome, some of the described patterns are frequent, such as the attenuation and/or absence of the distal interphalangeal (DIP) flexion crease on the third and fourth joint of fingers, which limits movement and flexibility of the joints; increase in the hypotanar pattern (musculature in the palm below the fifth phalanx) and increase in ulna loops (NIIKAWA et al., 1982). Finger pad conformation is not only associated to Kabuki Syndrome, since the occurrence rate (gene penetration with expressivity) in the normal population is 3\% (JONES et al., 2013). According to Oliveira (2000), the presence of less evident dermatoglyphic patterns in Kabuki patients may influence the diagnosis of the syndrome. Thus, it is possible that some patients analyzed in this review, whose dermatoglyphic patterns had not been observed, the phenotype of dermatoglyphic patterns might be present with subtle expressivity.

In this systematic review, $65 \%$ of the patients analyzed presented mental retardation, a phenotype that was different from findings by Niikawa et al. (1988), in which $92 \%$ of patients showed this condition. In the literature, there are cases of Kabuki patients who do not present mental retardation (HALAL et al., 1989; PHILIP et al., 1992).

In relation to delayed postnatal development, results showed that 17 patients presented this phenotype (65\% of cases), which corresponds to a lower number when compared to more broad descriptive cases in the literature (83\% of cases), according to Niiwaka et al. (1988). The delay in development, characterized mainly by childhood delayed growth, could be related to lack of 
growth hormone (GH). Tawa et al. (1994) showed a decrease in the pulsatile secretion of GH in patients with Kabuki syndrome during deep sleep. This concept is compatible with a neurosecretory hormonal dysfunction, since no modulation/attenuation was found in the GH response.

Although the literature states that Kabuki syndrome has high incidence of developmental delay, the present review has identified 4 individuals that showed normal postnatal development. These data corroborate the findings of Kawame et al. (1999), which showed 6 patients with normal height, suggesting the possibility of adequate postnatal growth.

Among the 26 patients analyzed in this review, 19 presented malformations of the heart $(73 \%$ of the cases). According to Digilio et al. (2017), 28 to 80\% of Kabuki Syndrome cases present cardiac complications, as indicated by the results found in this study. In the literature, cardiac alterations are reported as cardiac murmur, aortic coarctation, atrial and ventricular septal defect, aortic aneurysm and malformation of the aorta (PETERSON-FALZONE et al., 1997). All cardiac complications found in this study fit the malformations described in the literature, with a greater focus on aortic coarctation, which is a more frequent anomaly (HUGHES; DAVIES, 1994).

Eight patients were tested and confirmed to have hearing impairment, accounting for approximately $30 \%$ of cases. According to Tekin et al. (2006), cases of deafness are found in $40 \%$ of patients with Kabuki Syndrome. There is little difference between results of the literature and those obtained in the current systematic review, however, it is possible that other patients in this review also presented some degree of deafness, which was most likely not evidenced in case reports because deafness was not the focus of those studies.

Deafness in Kabuki Syndrome can be attributed to otitis media and dysplasia, affecting the organ of Corti, the spiral ganglion and the cochlear region and are generally characterized as Mondini's dysplasia (IGAWA et al., 2000). Otitis media is an ear infection that involves both innate and adaptive immune system responses. The condition is generally common in children (ROVERS et al., 2004). Complications that derive from otitis media and may cause deafness include the occurrence of tympanic membrane perforations, formation of tympanosclerosis plaques, adhesion of the tympanic membrane to the ossicular chain or promontory, formation of retraction pockets, cholesteatoma and ossicular chain fixation (BALBANI; MONTOVANI, 2003). Furthermore, otitis media originates as infections of the middle ear, therefore it is plausible to postulate that most cases of deafness in Kabuki syndrome occur due to high 


\section{Revinter}

incidence of otitis media, since Kabuki patients are generally more susceptible to infections (60 to 73\%) (GILLS; GROSS-KIESELSTEIN, 1990; HOFFMAN et al. 2005).

This high incidence of infections may be associated with impairment of the immune system, since it is common to find patients with serious immune dysfunctions. As seen in Table 3,13 patients showed incidence of infections (50\% of cases) and 8 patients showed alterations in the immune system (30\% of cases). The most frequent infections found in the literature are recurrent cases of otitis media, pneumonia and urinary tract infections (CHRZANOWSKA et al., 1998). In the present study, there were identified cases of human immunodeficiency virus (HIV-1) immunoglobulin A (IgA) and immunoglobulin G (IgG), ITP (Immune Thrombocytopenic Purpura) and low CD8 T lymphocyte expression (EWART-TOLAND et al., 1998; CHRZANOWSK et al., 1998; KAWAME et al., 1999).

Gastrointestinal disorders are also common in patients with Kabuki Syndrome and may be related to susceptibility to infections and dysfunctions of the immune system. Six patients were found to have immune deficiencies. Their gastrointestinal mucosa showed high numbers of macrophages, T and B lymphocytes (PEDRUZZI, 2002 apud PEREIRA et al., 2008). Presence of IgA indicates the first gastrointestinal defense response (PEREIRA et al., 2008) and patients with low IgA levels may correspond to phenotypes that show lower intestinal immune response, leading to gastrointestinal complications. Another factor that is also related to deficiencies in the immune system is improper maintenance of the intestinal microbiota, which can lead to deviations of normal composition, resulting in gastrointestinal disturbances and development of diseases (MALOZI, 2010).

The literature describes the presence of renal function alterations and/or malformations in patients with Kabuki Syndrome. Here we have found that 5 patients presented kidney hypoplasia, double collecting system and/or duplicate right kidneys (KAWAME et.al., 1999). Ewart-Toland et al. (1998) reported position and/or abnormal shape of the kidneys, duplication of the collecting system, hydronephrosis (excess fluid in the kidney), megalourethra (enlargement of the urethra) and dysplasias. Ewart-Toland et al. (1998) described a Kabuki Syndrome patient with renal failure due to dysplasia, which led to a necessary organ transplant, however, the patient survived only for a few years after transplantation. The authors further emphasize in the above-mentioned study that it is rare to find patients with Kabuki in advanced age groups due to multiple malformations and potentially fatal phenotypes caused by the syndrome. 
Several phenotypic and non-phenotypic characteristics were mentioned in this systematic review. However, only a few of these characteristics were discussed here, since many of them were only cited as part of the patients' descriptions in particular case reports analyzed, with no explanation for causes or origins. Such non-mentioned characteristics might be unrelated to Kabuki Syndrome.

Initially, patients of Kabuki syndrome had to be diagnosed according to the 5 main descriptive features, according to Lindsley et al. (2016). Nowadays, studies have shown records of Kabuki Syndrome patients who lack some of the main characteristics, such as patients 2, 5, 10 and 19 of Table 1. These patients showed no signs of postnatal development delay and received their diagnosis solely through DNA sequencing. Thus, it is feasible to assume that many patients with this syndrome had previously been diagnosed with other diseases, as DNA sequencing techniques for Kabuki diagnosis had not yet been used until recently. Currently, the minimum criterion for diagnosis of Kabuki Syndrome encompasses the phenotypes of peculiar physiognomy present in the patients, which allows for verification soon after birth. Facial characteristics tend to get accentuated throughout the patients' lives (ADAM; HUDGINS, 2005), however, confirmation of diagnosis requires genotyping.

It is common to find patients with Kabuki Syndrome that have been previously diagnosed with other syndromes due to similarities of phenotypes, such as Van der Woude Syndrome and DiGeorge Syndrome (ADAM; HUDGINS, 2005). Van der Woude syndrome is characterized by the presence of cleft palate, lower lip and uvula (Vélez et al., 1995), which are also common with Kabuki syndrome. Patients with DiGeorge Syndrome are also confounded for patients with Kabuki Syndrome, as both syndromes lead to cardiovascular anomalies, palate malformations, developmental delays, mental retardation and facial malformations (LI et al., 1996). The differentiation of these syndromes occurs through genetic sequencing, since Van der Woude Syndrome is related to a mutation on chromosome 1, DiGeorge syndrome relates to a deletion on chromosome 22 and Kabuki syndrome is related to a mutation on chromosome 12 (MAKITA et al. 1999; MCDONALD-MCGRINN et al., 2006).

Another syndrome that can be confounded with Kabuki is Charge Syndrome. This syndrome is characterized by multiple congenital anomalies that form the name of the disease (Coloboma, Hearts defects, Atresia, Retardation, Genital anomalies and Ear anomalies) (VERLOES, 2005). The most difficult period for differentiation and proper diagnosis of these two syndromes occurs during childhood. However, as early as the first months of life, patients with Kabuki Syndrome begin to present the characteristic facial malformations, therefore facilitating proper diagnosis 
(MING et al., 2003). It is also possible to employ genetic sequencing for proper diagnosis, since Charge Syndrome corresponds to mutations in chromosome 8 (VISSERS et al., 2004).

\section{FINAL CONSIDERATIONS}

Kabuki Syndrome is rare and presents early morbidity due to multiple malformations and typical physiognomy present in the patients. Despite reports of increased incidence, Kabuki is still poorly reported in the scientific world. An important consideration to be taken into account in this context is that the scientific literature descriptions do not present a consensus regarding the phenotypic characteristics of the syndrome, which difficult its diagnosis. In this study we were able to show that both main and secondary characteristics of the syndrome present variations in presence (penetration) and intensity (expression) in affected individuals, therefore, characterization through phenotypes becomes limited, which makes genetic verification a necessity. Here we suggest further studies using animal models in order to expand the current knowledge and elucidate diagnostic phenotypes as well as mechanisms related to Kabuki syndrome.

\section{REFERENCES}

ADAM, M.P.; HUDGINS, L. Kabuki syndrome: a review. Clinical Genetics, v. 67, n. 3, p. 209-219, 2005. DOI: 10.1111/j.1399-0004.2004.00348.x.

BADALATO, L.; FARHAN, S. M. K.; DILLIOTT, A. A.; CARE4RARE CANADA CONSORTIUM; BULMAN, D. E.; HEGELE, R. A.; GOOBIE, S. KMT2D p.Gln357His segregating in a family with autosomal dominat choanal atresia strengthens the Kabuki/CHARGE connection. American Journal of Medical Genetics, v. 173, n. 1, p. 183189. DOI: 10.1002/ajmg.a.38010.

BALBANI, A. P. S.; MONTOVANI, J. C. Impacto das otites médias na aquisição da linguagem em crianças. The Journal of Pediatrics, v. 79, n. 5, p. 391-396, 2003. DOI: 10.1590/S0021-75572003000500005.

BÖGERSHAUSEN, N.; ALTUNOGLU, U.; BELEGGIA, F.; YIGIT, G.; KAYSERILI, H.; NÜRNBERG, P.; LI, Y.; ALTMÜLLER, J.; WOLLNIK, B. Anunsually presention of Kabuki syndrome with orbital cysts, microcephtalmia, and cholestasis with bile buct paucity.

American Journal of Medical Genetics, v. 170, n. 12, p. 3282- 3288, 2016. DOI: 10.1002/ajmg.a.37931.

CARVALHO, Q. C. M.; CARDOSO, M. V. L. M. L.; OLIVEIRA, M. M. C.; LUCIO, I. M. L. Malformação Congênita: Significado da experiência para os pais. Ciência, Cuidado e Sáude, v. 5, n. 3, p. 389-397, 2006. DOI: 10.4025/cienccuidsaude.v5i3.5039 CHRZANOWSKA, K. H.; KRAJEWSKA-WALASEK, M.; KUŚ, J.; MICHAŁKIEWICZ, J.; MAZIARKA, D.; WOLSKI, J. K.; BRECEVIC, L.; MADALIŃSKI, K. Kabuki (NiikawaKuroki) syndrome associated with immunodeficiency. Clinical Genetics, v. 53, n. 4, p. 308312, 1998. DOI: 10.1111/j.1399-0004.1998.tb02702.x 
DIGILIO, M. C.; GNAZZO, M.; LEPRI, F.; DENTICI, M. L.; PISANESCHI, E.; BABAN, A.; PASSARELLI, C.; CAPOLINO, R.; ANGIONI, A.; NOVELLI, A.; MARINO, B.; DALLAPICCOLA, B. Congenital heart defects in molecular proven Kabuki syndrome patients. American Journal os Medical Genetics, v. 173, n. 11, p. 2912-2922, 2017. DOI: 10.1002/ajmg.a.38417.

EWART-TOLAND, A.; ENNS, G. M.; COX, V. A.; MOHAN, G. C.; ROSENTHAL, P.; GOLABI, M. Severe congenital anomalies requiring transplantions in children with Kabuki syndrome. American Journal of Medical Genetics, v. 80, n. 4, p. 362-367, 1998. DOI: 10.1002/(SICI)1096-8628(19981204)80:4<362::AID-AJMG11>3.0.CO;2-W.

GENEVIÉVE, D.; AMIEL, J.; VIOT, G.; LE MERRER, M.; SANLAVILLE, D.; URTIZBEREA, A.; GÉRARD, M.; MUNNICH, A.; CORMIER-DAIRE, V.; LYONNET, S. Atypical findings in kabuki syndrome: report of 8 patients in a series of 20 and review of the literature. American Journal of Medical Genetics, v. 129A, p. 64-68, 2004. DOI 10.1002/ajmg.a.30144

GILLS, R.; GROSS-KIESELSTEIN, E. The Niikawa-Kuroki (Kabuki make-up) syndrome in a moslem arab child. Clinical Genetics, v. 38, n. 5, p. 387-381, 1990. DOI: 10.1111/j.13990004.1990.tb03599.x.

HALAL, F.; GLEDHILL, R.; DUDKIEWICZ, A. Autosomal dominant inheritance of the Kabuki make-up (Niikawa-Kuroki) syndrome. American Journal of Medical Genetics, v. 33, n. 3, p. 376-381, 1989. DOI: 10.1002/ajmg.1320330317.

HOFFMAN, J. D.; CIPRENO, K. L.; SULLIVAN, K.; KAPLAN, P. B.; MCDONALDMCGINN, D. M.; ZACKAI, E. H.; MING, J. E. Immune abnormalities are a frequent manifestation of Kabuki syndrome. American Journal of Medical Genetics, v. 135A, n. 3, p. 278-281, 2005. DOI: 10.1002/ajmg.a.30722.

HUGHES, H. E.; DAVIES, S. J. Coarctation of the aorta in Kabuki syndrome. Archieves of Disease in Childhood, v. 70, n. 6, p. 512-514, 1994. DOI: 10.1136/adc.70.6.512.

IGAWA, H. H.; NISHIZAWA, N.; SUGIHARA, T.; INUYAMA, Y. Inner ear abnormalities in Kabuki make-up syndrome: Report of three cases. American Journal of Medical Genetics, n. 92, v. 2, p. 87-89, 2000. DOI: 10.1002/(SICI)1096-

8628(20000515)92:2<87::AID-AJMG1>3.0.CO;2-G.

JONES, K. L.; JONES, M. C.; DEL CAMPO, M. D. Smith's recognizable patterns of human malformation. 7. Ed. Estados Unidos: Elsevier Health Science, 2013. 979 p. JORDE, L. B.; CAREY, J. C.; BAMSHAD, M. J.; WHITE, R. L. Genética Médica. 3. Ed. Rio de Janeiro: Elsevier, 2004. 415 p.

JÚNIOR, I. M. B. A.; IANOTTI, G, C. Ética e medicina preditiva. Revista Brasileira de Saúde Materno Infantil, v. 10, supl. 2, p. 5377-5382, 2010. DOI: 10.1590/S151938292010000600016.

KARAGIANNI, P.; LAMBROPOULOS, V.; STERGIDOU, D.; FRYSSIRA, H.; CHATZIIOANNIDIS, I.; SPYRIDAKIS, I. Recurrent giant cell fibroblastoma: Malignancy predisposition in Kabuki syndrome revisited. American Journal of Medical Genetics, v. 170a, n. 5, p. 1333-1338, 2016. DOI: 10.1002/ajmg.a.37584.

KAWAME, H.; HANNIBAL, M.; HUDGINS, L.; PAGON, R. Phenotypic spectrum and management issues in Kabuki syndrome. The Journal of Pediatrics, v. 134, n. 4, p. 480-485, 1999. DOI: 10.1016/S0022-3476(99)70207-6.

KUROKI, Y.; SUZUKI, Y.; CHYO, H.; HATA, A.; MATSUI, I. A new malformation syndrome of long palpebral fissures, large ears, depressed nasal tip, and a skeletal anomalies associated with postnatal dwarfism and mental retardation. The Journal of Pediatrics, v. 99, n. 4, p. 570-573, 1981. DOI: 10.1016/S0022-3476(81)80256-9. 
LEPRI, F. R.; COCCIADIFERRO, D.; AUGELLO, B.; ALFIERI, P.; PES, V.; VANCINI, A.; CACIOLO, C.; SQUEO, G. M.; MALERBA, N.; ADIPIETRO, I.; NOVELLI, A.; SOTGIU, S.; GHERARDI, R.; DIGILIO, M. C.; DALLAPICCOLA, B.; MERLA, G. Clinical and neurobehavioral geatures of three noval Kabuki syndrome patients with mosaic KMT2D mutations and review of literature. International Journal of Molecular Sciences, v. 19, n. 1, p. 82-92, 2017. DOI: 10.3390/ijms19010082.

LI, M.; ZACKAI, E. H.; NIIKAWA, N.; KAPLAN, P.; DRISCOLL, D. A. Kabuki syndrome is not caused by a microdeletion in the DiGeorge/velocardiofacil chromosomal region within 22q11.2. American Journal of Medical Genetics, v. 65, n. 2, 1996. DOI: 10.1002/(SICI)1096-8628(19961016)65:2<101::AID-AJMG3>3.0.CO;2-V. LINDSLEY, A. W.; SAAL, H. M.; BURROW, T. T.; HOPKIN, R. J.; SHCHELOCHKOV, O.; KHANDELWAL, P.; XIE, C.; BLEESING, J.; FILIPOVICH, L.; RISMA, K.; ASSA'AD, A. H.; ROEHRS, P. A.; BERNSTEINS, J. A. Defect of B cell terminal differentions in patients with type-1 Kabuki syndrome. The Journal of Allergy and Clinical Immunology, v. 137, n. 1, p. 179-187e10, 2016. DOI: 10.1016/j.jaci.2015.06.002.

LONG, A.; SINKOVSKAYA, E. S.; EDMONDSON, A. C.; ZACKAI, E.; SCHRIERVERGANO, S. A. Kabuki syndrome as a cause of non-immune fetal hydrops/ascites. American Journal of Medical Genetics, v. 170, n. 12, p. 3333-3337, 2016. DOI: 10.1002/ajmg.a.37956.

LU, J.; MO, G.; LING, Y. JI, L. A novel KMT2D mutation resulting in Kabuki syndrome: A case report. Molecular Medicine Reports, v. 14, n. 4, p. 3641-3645, 2016. DOI: 10.3892/mmr.2016.5683.

MAKITA, Y.; YAMADA, K.; MIYAMOTO, A.; OKUNO, A.; NIIKAWA, N. Kabuki makeup syndrome is not caused by microdeletion close to the van der Woude syndrome critical region at 1q32-q41. American Journal of Medical Genetics, v. 86, n. 3, p. 285-288, 1999. DOI: 10.1002/(SICI)1096-8628(19990917)86:3<285::AID-AJMG18>3.0.CO;2-E.

MALOZI, M. C. A importância da microbiota no sistema imunológico. Pediatria Moderna, v. 48, n. 10, p. 387-392, 2010.

MATSUMOTO, N.; NIIKAWA, N. Kabuki make-up Syndrome: A Review. American Journal of Medical Genetics, v. 117C, n. 1, p. 57-65, 2003. DOI: 10.1002/ajmg.c. 10020. MCDONALD-MCGINN, D. M.; REILLY, A.; WALLGREN-PETTERSSON, C.; HOYME, H. E.; TANG, S. P.; ADAM, M. P.; ZACKAI, E. H.; SULLIVAN, K E. Malignancy in chromosome 22q11.2 deletion syndrome (DiGeorge syndrome/velocardiofacial syndrome). American Journal of Medical Genetics, v. 140A, n. 8, p. 906-909, 2006. DOI: 10.1002/ajmg.a.31199.

MCGAUGHRAN, J.; AFTIMOS, S.; JEFFERERIES, C.; WINSHIP, I. Clinical phenotypes of nine cases of Kabuki syndrome from New Zealand. Clinical Dysmorphology, v. 10, n. 4, p. 257-262, 2001. DOI: 10.1097/00019605-200110000-00004.

MHANNI, A. A.; CROSS, H. G.; CHUDLEY, A. E. Kabuki syndrome: description of dental findings in 8 patients. Clinical Genetics, v. 56, n. 2, p. 154-157, 1999. DOI: 10.1034/j.13990004.1999.560211.x.

MING, J. E.; RUSSEL, K. L.; BASON, L.; MCDONALD-MCGINN, D. M.; ZACKAI, E. H. Coloboma and other ophthalmologic anomalies in Kabuki syndrome: Distinction from charge association. America Journal of Medical Genetics, v. 123A, n. 3, p. 249-252, 2003. DOI: 10.1002/ajmg.a.20277.

MIYAKE, N.; MIZUNO, S.; OKAMOTO, N.; OHASHI, H.; SHIINA, M.; OGATA, K.; TSURUSAKI, Y.; NAKASHIMA, M.; SAITSU, H.; NIIKAWA, N.; MATSUMOTO, N. KMD6A Point mutation cause Kabuki syndrome. Human Mutation, v. 34, n. 1, p. 108-110, 2013. DOI: $10.1002 /$ humu.22229. 
NASSAU, F. F.; GENTIL, P.; LOBATO, S. R. U.; COSTA, P. I. M.; ROCHA, V. Correlação entre perfil datiloscópico e performance nos testes de 12 minutos e de uimpulsão horizontal em jovens do sexo masculino. 2011. Disponível em< https://www.researchgate.net/publication/28130372> Acesso em: 20 de maio 2018. NG, S. B.; BIGHAM, A. W.; BUCKINGHAM, K. J.; HANNIBAL, M. C.; MCMILLIN, M. J.; GILDERSLEEVE, H. I.; BECK, A. E.; TABOR, H. K.; COOPER, G. M.; MEFFORD, H. C.; LEE, C.; TURNER, E. H.; SMITH, J. D.; RIEDER, M. J.; YOSHIURA, K.; MATSUMOTO, N.; OHTA, T.; NIIKAWA, N.; NICKERSON, D. A.; BAMSHAD, M. J.; SHENDURE, J. Exome sequencing identifies MLL2 mutation as a cause of Kabuki syndrome. Nature Genetics, v. 42, n.9, p. 790-793, 2010. DOI: 10.1038/ng.646. NIIKAWA, N.; KUROKI, Y.; KAJII, T.; MATSUURA, N.; ISHIKIRIYAMA, S.; TONOKI, H.; ISHIKAWA, N.; YAMADA, Y.; FUJITA, M.; UMEMOTO, H.; IWAMA, Y.; KONDOH, I.; FUKUSHIMA, Y.; NAKO, Y.; MATSUI, I.; URAKAMI, T.; ARITAKI, S.; HARA, M.; SUZUKI, Y.; CHYO, H.; SUGIO, Y.; HASEGAWA, T.; YAMANAKA, T.; TSUKINO, R.; YOSHIDA, A.; FUNAKI, H.; ISHITOBI, K.; OGURA, S.; FURUMAE, T.; IESHIMA, A.; FUNAKI, H.; ISHITOBI, K.; OGURA, S.; FURUMAE, T.; YOSHINO, M.; TSUJI, Y.; KONDOH, T.; MATSUMOTO, T.; ABE, K.; HARADA, N.; MIIKE, T.; OHDO, S.; NARITOMI, K.; ABUSHWEREB, A. K.; BRAUN, O. H.; SCHMID, E.; OPITS, J. M.; REYNOLDS, J. F.; Kabuki make-up (Niikawa-Kuroki) syndrome: A study of 62 patients. American Journal of Medical Genetics, v. 31, n. 3, p. 565-589, 1988. DOI: 10.1002/ajmg.1320310312.

NIIKAWA, N.; MATSUURA, N.; FUKUSHIMA, Y.; OHSAWA, T.; KAJII, T. Kabuki make-up syndrome: a syndrome of mental retardation, unusual facies, large and protruding ears, and postnatal growth deficiency. The Journal of Pediatrics, v. 99, n. 4, p. 565-569, 1981. DOI: 10.1016/S0022-3476(81)80255-7.

NIIKAWA, N; KUROKI, Y.; KAJII, T. The dermatoglyphic pattern of the Kabuki make-up syndrome. Clinical Genetics, v. 21, n. 5, p, 315-320, 1982. DOI: 10.1111/j.13990004.1982.tb01378.x. OLIVEIRA, G. S.; Estudo Genético-Clínico de indivíduos com características da Síndrome de Kabuki. 2000. Dissertação (Mestrado em Ciências Médicas) - Universidade Estadual de Campinas, Campinas, 2000.

PEREIRA, A. C.; MOURA, S. M.; CONSTANT, P. B. L. Alergia alimentar: sistema imunológico e principais alimentos envolvidos. Semina: Ciência biológica e da saúde, v. 29, n. 2, p. 189-200, 2008. DOI: 10.5433/1679-0367.2008v29n2p189.

PETERSON-FALZONE, S. J.; GOLABI, M.; LALWANI, A. K. Otolaryngologic manifestations of Kabuki syndrome. International Journal of Pediatric

Otorhinolaryngology, v. 38, n. 3, p. 227-236, 1997. DOI: 10.1016/S0165-5876(96)01443-7. PHILIP, N.; MEINECKE, A.; DAVID, A.; DEAN, J.; AYME, S.; CLARK, R.; GROSSKIESELSTEIN, E.; HOSENFELD, D.; MONCLA, A.; MULLER, D.; SILENGO, M.; TARIVERDIAN, G. Kabuki make-up (Niikawa-Kuroki) syndrome: a study of 16 nonJapanese cases. Clinical Dysmorphology, v. 1, n. 2, p. 63-77, 1992. DOI:

10.1016/j.joto.2014.12.002.

ROVERNS, M. M.; SCHILDER, A. G. M.; ZIELHUIS, G. A.; ROSENFELD, R. M. Otitis media. The Lancet, v. 363, n. 9414, p. 1080, 2004. DOI: 10.1016/S0140-6736(04)15495-0. SAMPAIO, R. F.; MANCINI, M. C. Estudo de revisão sistemática: um guia para a síntese criteriosa da evidencia científica. Revista Brasileira de Fisioterapia, v. 11, n. 1, p. 83-89, 2007. DOI: 10.1590/S1413-35552007000100013.

SCHULZ, Y.; FREESE, L.; MÄNZ, J.; ZOLL, B.; VÖLTER, C.; BROCKMANN, K.; BÖGERSHAUSEN, N.; BECKER, J.; WOLLNIK, B.; PAULI, S. CHARGE and Kabuki 
syndrome: a phenotypic and molecular link. Human Molecular Genetics, v. 23, n. 16, p. 4396-4405, 2014. DOI: 10.1093/hmg/ddu156.

TAWA, R.; KAINO, Y.; ITO, T.; GOTO, Y.; KIDA, K.; MATSUDA, H. A case of Kabuki make-up syndrome with central diabetes insipidus and growth hormone neurosecretory dysfunction. Pediatrics International, v. 36, n. 7, p. 412-415, 1994. DOI: 10.1111/j.1442200X.1994.tb03212.x.

TEKIN, M.; FITOZ, S.; ARICI, S.; CETINKAYA, E.; INCESULU, A. Niikawa-Kuroki (Kabuki) syndrome with congenital sensorineural deafness: Evidence for a wide spectrum of inner ear abnormalities. International Journal of Pediatric Otorhinolaryngology, v. 70, n. 5, p. 885-889, 2006. DOI: 10.1016/j.ijporl.2005.09.025.

VAN-LAARHOVEN, P.M.; NEITZEL, L. R.; QUINTANA, A. M.; GEIGER, E. A.; ZACKAI, E. H.; CLOUTHIER, D. E.; ANTINGER, K. B.; MING, J. E.; SHAIKH, T. H. Kabuki syndrome genes KMT2D and KDM6A: functional analyses demonstrate critical roles in craniofacial, heart and brain development. Human Molecular Genetics, v. 24, n. 15, p. 4443-4453, 2015. DOI: 10.1093/hmg/ddv180.

VÉLEZ, A.; ALAMILLOS, F. L.; DEÁN, A.; RUIZ-MASERA, J. J. Congenital lower lip pits (Van der Woude syndrome). Jornal of the American Academy of Dermatology, v. 32, n. 3, p. 520-521, 1995. DOI: 10.1016/0190-9622(95)90095-0.

VERLOES, A. Updated diagnostic criteria for CHARGE syndrome: A proposal. American Journal of Medical Genetics, v. 133A, n. 3, p. 306-308, 2005. DOI: 10.1002/ajmg.a.30559. VISSERS, L. E. L.; RAVENSWAAIJ, C. M. A.; ADMIRAAL, R.; HURST, J. A.; VRIES, B. B. A.; JANSSEN, I. M.; VLIET, W. A.; HUYS, E. H. L. P. G.; JONG, P. J.; HAMEL, C. J.; SCHOENMAKERS, E. F. P. M.; BRUNNER, H. G.; VELTMAN, J. A.; KESSEL, G.

Mutations in a new member of the chromodomain gene family cause CHARGE syndrome. Nature Genetics, v. 36, n. 9, p. 955-957, 2004. DOI: 10.1038/ng1407.

XIN, C.; WANG, C.; WANG, Y.; ZHAO, J.; WANG, L.; LI, R.; LIU, J. Identification of novel KMT2D mutationin two Chinese children with Kabuki syndrome: a case report and systematic literature review. BMC Medical genetics, v. 19, n. 1, 6 p. 2018. DOI: 10.1186/s12881-018-0545-5.

\footnotetext{
' Universidade Presbiteriana Mackenzie e Faculdade de Ciências da Saúde IGESP.

iiFaculdade de Medicina Veterinária e Zootecnia da Universidade de São Paulo.

iiiFaculdade de Medicina Veterinária e Zootecnia da Universidade de São Paulo.

ivKiran C. Patel College of Osteopathic Medicine, Institute for Neuro-Immune Medicine, Nova Southeastern University.

vUniversidade Presbiteriana Mackenzie e Faculdade de Ciências da Saúde IGESP.
} 